\title{
Ответные реакции растений картофеля при обработке смесями бактерий Bacillus subtilis с иммуномодуляторами в условиях водного дефицита и вирусного заражения
}

\author{
() Ж. Н. Калацкая ${ }^{1 *}$, Е. Л. Недведь ${ }^{1}$, Н. В. Балюк ${ }^{1}$, К. М. Герасимович ${ }^{1}$, Е. И. Рыбинская ${ }^{1}$, \\ И. А. Овчинников ${ }^{1}$, Н. А. Копылова ${ }^{1}$, Л. Г. Яруллина ${ }^{2}$, Н. А. Ламан ${ }^{1}$ \\ ${ }^{1}$ Институт экспериментальной ботаники НАН Беларуси \\ Республика Беларусь, 220072 г. Минск, улица Академическая, 27. \\ ${ }^{2}$ Институт биохимии и генетики Уфримского научного центра РАН \\ Россия, Республика Башкортостан, 450054 г. Уфа, проспект Октября, 71. \\ *Email: kalatskayaj@mail.ru
}

Обработка смесями Bacillus subtilis 47 с МеЖ или с СК+МеЖ, зараженных Y-вирусом растений картофеля и выращиваемых в условиях водного дефицита, способствует активному росту растений в сравнении с инфицированными и снижению вирусной нагрузки на $16 \%$ и $12 \%$ соответственно. При этом выявлено увеличение содержания пролина и общей пероксидазной активности в листьях растений. Применение $B$. subtilis отдельно или с СК не вызвало положительного эффекта по снижению инфицирования или сохранению роста растений в условиях недостаточного влагообеспечения.

Ключевые слова: Solanum tuberosum L., Bacillus subtilis 47, салициловая кислота (СК), метилжасмонат (МеЖ), Ү вирус картофреля, пролин, пероксидаза

Картофель занимает одно из лидирующих мест в мировом валовом производстве. По офрициальным данным FAOSTAT мировой урожай данной культуры в 2019 году составил свыше 370 млн метрических тонн, а общая посевная площадь, отводимая под картофель, насчитывала 17,34 млн гектаров [1]. Повсеместно наблюдаемые ухудшения влагообеспечения почвы, связанные с уменьшением и неравномерностью выпадения осадков в сочетании с повышенным температурным режимом, являются существенным лимитирующим фактором роста и развития растений картофеля и формирования урожая клубней [2,3]. Кроме того, ослабленные растения более уязвимы для различных фритопатогенов. Так, например, широко распространённый Ү вирус картофреля, может вызывать снижение урожайности культуры более чем на 50\% [4].

Одним из решений экологически безопасного повышения устойчивости растений к неблагоприятным факторам среды и вирусным заболеваниям является применение бактерий рода Bacillus, способных индуцировать устойчивость к широкому кругу стрессоров [5-9]. Защитный спектр бактерий рода Bacillus можно значительно расширить, комбинируя их с сигнальными молекулами, например, с жасмоновой или салициловой кислотами. Однако научные публикации содержат противоречивые сведения о взаимодействии этих молекул и их сигнальных путей при комплексном действии неблагоприятных фракторов различной природы [5, 8-10].

Целью работы являлось изучение ответных реакций растений картофеля к совместному действию дефицита почвенной влаги и заражению Ү-вирусом при обработке растений смесями бактерий Bacillus subtilis с салициловой кислотой и/или метилжасмонатом. 
Опыты проведены в контролируемых лабораторных условиях на микроклонально размноженных растениях картофеля белорусской селекции сорта Бриз. Адаптацию растений-регенерантов осуществляли на почвогрунте на основе верхового торфа с добавлением элементов питания в виде минеральных солей. Адаптированные растения обрабатывали путем опрыскивания листовой поверхности различными вариантами смесей бактерий Bacillus subtilis 47 (биопрепарат Карфил, производство Институт микробиологии НАН Беларуси) в концентрации $1 \times 10^{7}$ KОЕ с метиловым эфиром жасмоновой

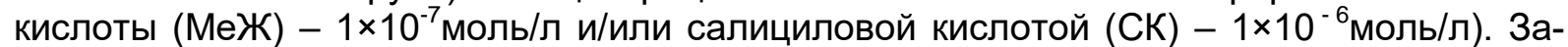
ражение $\mathrm{Y}$ - вирусом картофеля (ҮВК) проводили путём натирания клеточным соком доноров листьев растений картофеля при помощи мелкозернистой наждачной бумаги через 3 суток после обработки. Моделирование условий почвенной засухи начинали через неделю после обработки растений и продолжали в течение 2-х недель до появления симптомов повреждений на листьях. Влажность почвогрунта в опытном варианте $(40-45 \%$ от полной влагоёмкости (ПВ)) достигалась снижением полива растений. Степень заражения картофеля Y- вирусом определяли с помощью иммуноферментного анализа (ИФА) согласно инструкции [11]. Пробы отбирали через 14 дней после инфрицирования. Содержание пролина определяли по методу Bates с соавт. [12], общую активность растворимой пероксидазы по Бояркину [13], используя в качестве хромогенного субстрата бензидин. Анализ состава и содержания веществ фенольной природы проводили методом ВЭЖХ (в настоящей статье данные не приводятся в связи с неполной идентификацией индивидуальных соединений). Статистическую обработку данных осуществляли общепринятыми методами, на диаграммах указаны средние значения с отклонениями, указывающими величину стандартной ошибки средней арифметической.

В условиях водного дефицита обработка растений B.subtilis не способствовала уменьшению заражения листьев картофеля, однако при использовании смесей бактерий с МеЖ и МеЖ+СК выявлено снижение уровня инфицирования на $16 \%$ и 12\% соответственно (Рис. 1).

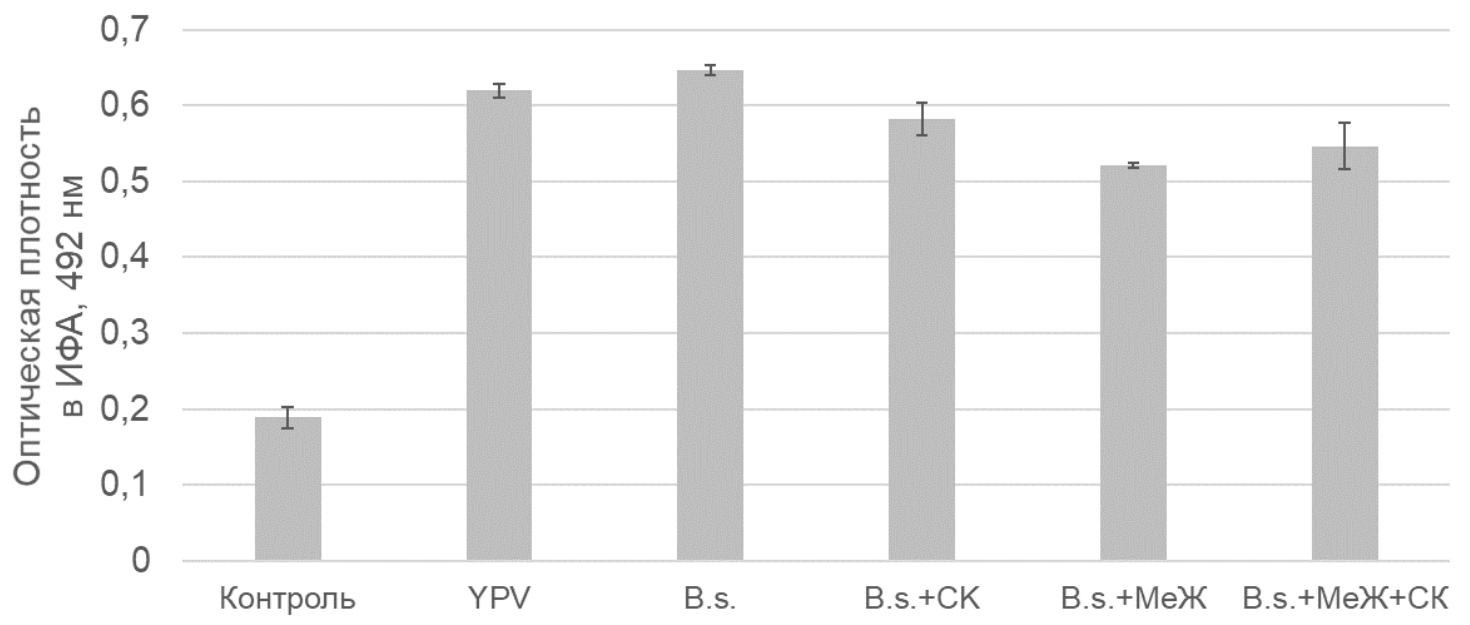

Рис. 1. Оптическая плотность в ИФА зараженных Ү-вирусом листьев растений картофреля при обработке Bacillus subtilis с иммуномодуляторами, выращиваемых в условиях водного дефицита

Инфицирование вызвало торможение роста побегов и снижение их длины по сравнению с контролем на 23,2\%. Применение B. subtilis в смеси с МеЖ способствовало сохранению роста, а смесь B.subtilis c МеЖ + СК ускоряла рост, длина побегов увеличилась на 14,3\% по сравнению с контрольными растениями, выращиваемыми при водном десиците (Рис. 2). 


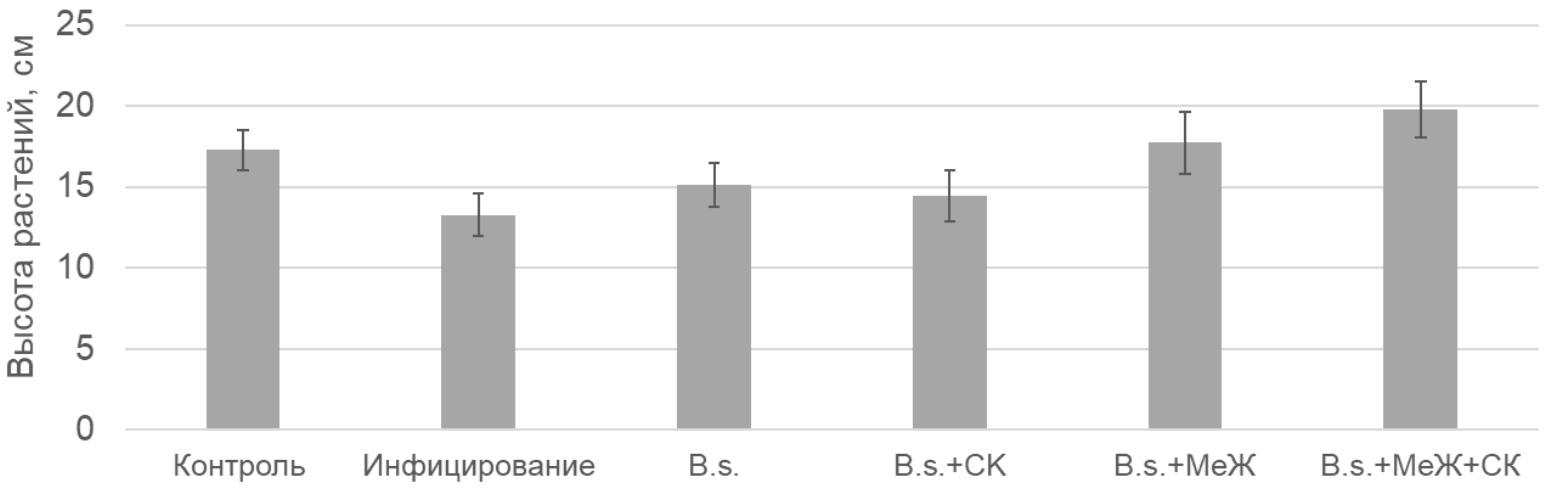

Рис. 2. Высота растений картофреля при обработке Bacillus subtilis с иммуномодуляторами, зараженных Y-вирусом и выращиваемых в условиях водного дефицита

Заражение растений Ү-вирусом на фоне водного дефицита привело к снижению содержания пролина. Максимальное накопление пролина на $89 \%$ по отношению к здоровым растениям и практически в 3 раза по отношению к инфицированным отмечено в варианте обработки смесью B.subtilis + СК. Опрыскивание комплексом B.subtilis с СК и МеЖ способствовало увеличению пролина на 39\% по отношению к здоровым растениям и в 2,2 раза к инфицированным. При обработках B.subtilis и B.subtilis + МеЖ содержание пролина оставалось на уровне незараженных растений (Рис. 3).

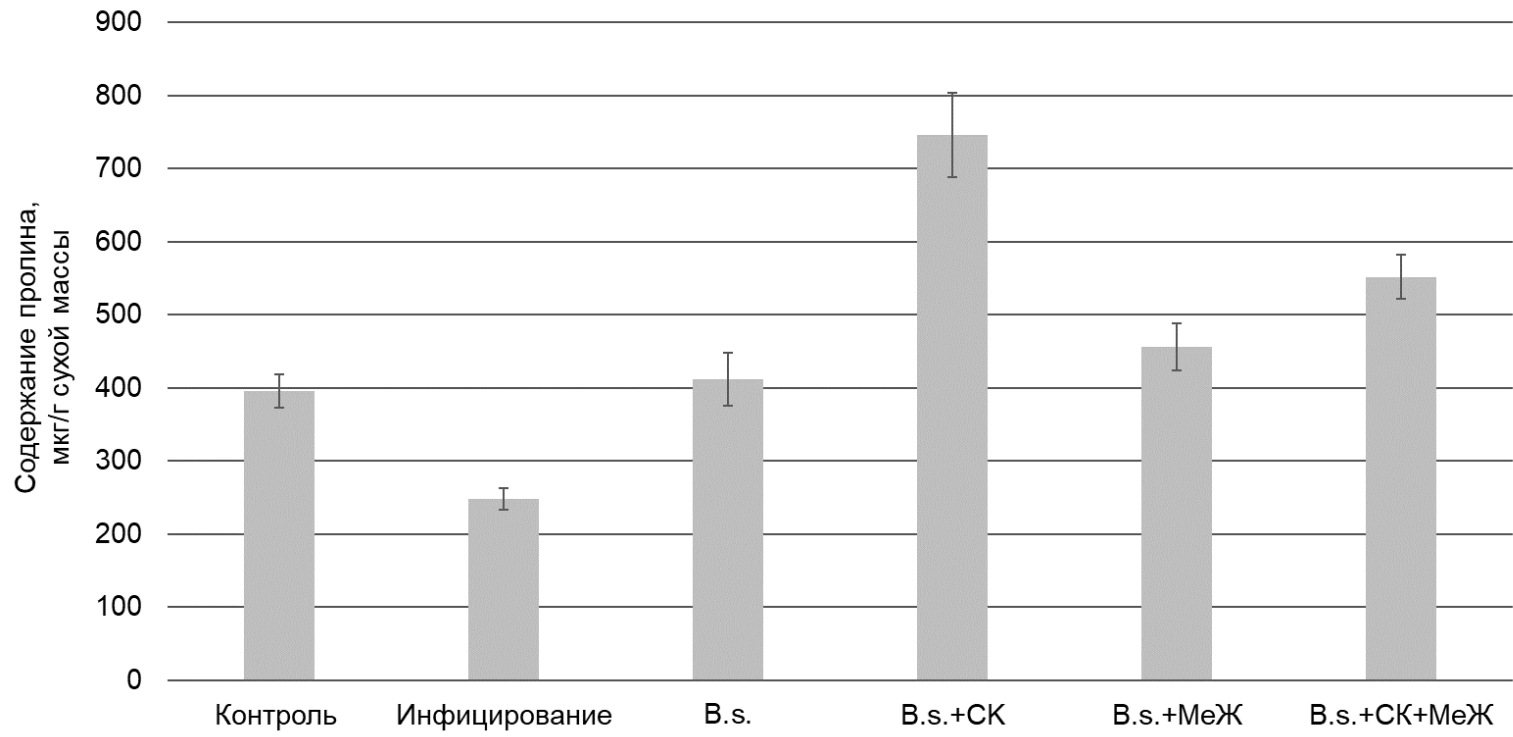

Рис. 3. Содержание пролина в листьях растений картофеля при обработке Bacillus subtilis с иммуномодуляторами, зараженных Y-вирусом и выращиваемых в условиях водного дефицита

Заражение Ү-вирусом вызвало увеличение общей пероксидазной активности практически в 2 раза в листьях контрольных растений, а применение смесей B.subtilis + МеЖ и B.subtilis с СК и МеЖ способствовало увеличению активности по сравнению с инфицированным контролем на 27,3 и 36,1\% соответственно (Рис. 4). 


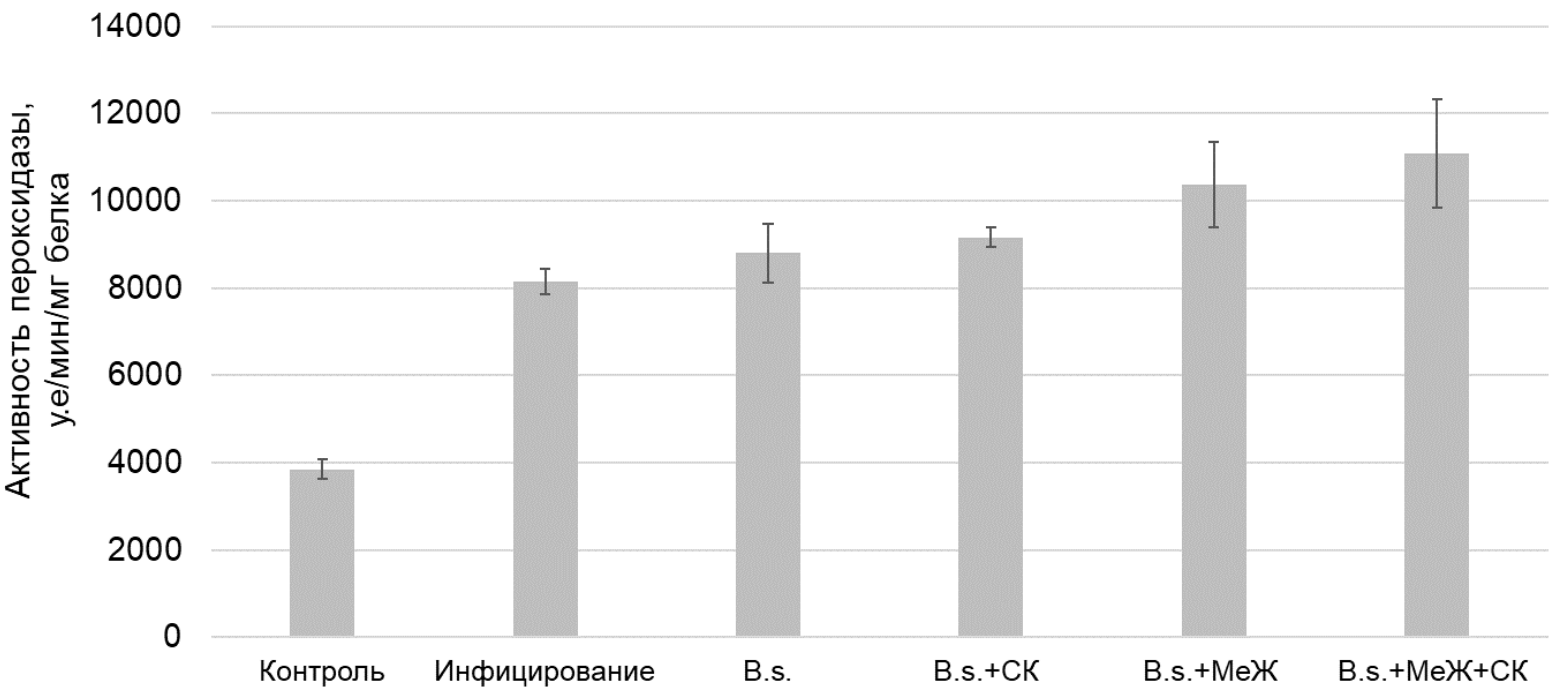

Рис. 4. Общая пероксидазная активность в листьях растений картофеля при обработке Bacillus subtilis с иммуномодуляторами, зараженных Y-вирусом и выращиваемых в условиях водного десицита

При водном дефиците и заражении Ү-вирусом общее содержание френольных соединений в вариантах опыта оставалось практически одинаковым, однако применение $B$. subtilis и смеси $B$. subtilis с СК вызвали значительные изменения в накоплении отдельных индивидуальных соединений. Так, выявлено увеличение содержания хлорогеновой, кофейной, фреруловой, салициловой кислот и рутина.

Таким образом установлено, что обработка смесями B.subtilis + МеЖ и B.subtilis с СК + МеЖ, зараженных Ү-вирусом растений картофеля и выращиваемых в условиях водного дефицита, способствует активному росту в сравнении с инфицированными растениями и снижению вирусной нагрузки на $16 \%$ и $12 \%$ соответственно. При этом выявлено увеличение содержания пролина и общей пероксидазной активности в листьях растений. Известно положительное влияние жасмонатов в формировании устойчивостии к неблагоприятным фракторам различной природы (действие засухи и грибной инфекции) [14]. Применение B.subtilis отдельно или в смеси с СК не вызвало положительного эффекта по снижению степени инфицирования или сохранению роста растений в условиях недостаточного влагообеспечения, однако в данных вариантах зарегистрировано значительное изменение содержания накопления индивидуальных фенольных соединений, высокое содержание эндогенной салициловой кислоты, а в варианте B.subtilis+ СК отмечено также максимальное накопление пролина. Известно, что салициловая кислота, участвует в регуляции метаболизма азота, пролина, синтеза глицин-бетаина, антиоксидантной системы защиты и водного потенциала в условиях стресса [15]. Полученные результаты свидетельствуют, что ответные реакции растений картофреля, инфрицированного Y- вирусом картофеля и выращиваемого в условиях водного дефицита, скорее всего, достигнуты действием сигнальных молекул - салициловой кислоты и метилжасмоната, а биологическая эфффективность штамма B. subtilis 47 оказалась невысокой.

Работа выполнена при фринансовой поддержке Белорусского республиканского фронда фрундаментальных исследований, грант Б20Р-154. 


\section{Литература}

1. Statistic // FAOSTAT. Food and Agricultural Organization of the United Nations. Peжим доступа: https://www.statista.com/statistics/382174/global-potato-production. - Дата доступа: 10.01.2021.

2. Пузанский Р. К. Метаболомика - современный подход при изучении адаптации растений картофреля к биотическому и абиотическму стрессу (обзор) // Сельскохозяйственная биология. 2018. Т. 53, № 1. С. 15-28.

3. Hamooh B. T. Sattar F. A., Wellman G., Mousa M. A. A. Metabolomic and biochemical analysis of two potato (Solanum tuberosum L.) cultivars exposed to in vitro osmotic and salt stresses // Plants. 2021. Vol. 10(1). P. 98.

4. Макарова С. С., Макаров В. В., Тальянский М. Э., Калинина Н. О. Устойчивость картофеля к вирусам: современное состояние и перспективы // Вавиловский журнал генетики и селекции. 2017. Т. 21. №1. С. 62-73.

5. Lastochkina O. B. Plant Growth-Promoting Bacteria: Biotic Strategy to Cope with Abiotic Stresses in Wheat / O.B. Lastochkina [et al.] // Wheat Production in Changing Environments. 2019. P.579-614.

6. Коломиец Э. И., Сверчкова Н. В., Мандрик-Литвинкович М. Н. Экологически безопасные биотехнологии для сельского хозяйства // Наука и инновации. 2019. № 3 (193). C. 4-9.

7. Гриц А. Н. Действие комплексного препарата с индукторами устойчивости к патогенам на инфицирование X-вирусом растений картофреля (Solanum tuberosum L.) / A. Н. Гриц [и др.] // Вес. Нац. акад. навук Беларусі. Сер. біял. навук. 2021. Т. 66, № 2. С. 159-168.

8. Бурханова Г. Ф. Эндофитные бактерии Bacillus spp. с РНКазной активностью и устойчивость картофреля к вирусам / Г.Ф. Бурханова [и др.] // Вавиловский журнал генетики и селекции. 2019. Т. 23, №7. С. 873-878

9. Сорокань А. В., Бурханова Г. Ф., Алексеев В. Ю., Максимов И. В. Влияние совместной обработки эндофитным штаммом бактерий Bacillus thuringiensis B-5351 и caлициловой кислотой на устойчивость растений картофеля к Phytophthora infestans (Mont.) de Bary // Вестник Томского государственного университета. Биология. 2021. № 53. C. $109-130$.

10. Максимов И. В. Влияние салициловой и жасмоновой кислот на компоненты про/антиоксидантной системы в растениях картофеля при фитофрторозе / И.В. Максимов [и др.] // Физиология растений. 2011. Т. 58, № 2. С. 243-251.

11. Инструкция по использованию иммуноферментного диагностического набора для определения вирусов картофеля / Рос. с.-х. акад. НПО по картофелеводству. М.:Коренево, 2016. - 8c.

12. Bates L. S., Waldren R. P., Teare J. D. Rapid Determination of Free Proline for Water-Stress Studies// Plant and Soil.1973. - V. 39, № 1. - P. 205-207.

13. Ермаков А. И., Арасимович В.В., Яраш Н. П. Методы биохимического исследования растений. Л.: Агропромиздат, Ленинград, 1987. 400 с. 
14. Луговая А. А. Влияние жасмоновой кислоты на продуктивность растений ячменя и их устойчивость к засухе и грибным инфекциям // Віснік Харківського Національного аграрного універсітету. Сер. Біологія. 2015. Віп. 3 (36). С. 54-61.

15. Miura K., Tada Y. Regulation of water, salinity, and cold stress responses by salicylic acid. Front. Plant Sci., 2014, 5: 4.

\section{Responses of potato plants treated mixtures Bacillus subtilis and immunomodulators in water deficiency conditions and viral infection}

J. N. Kalatskaja ${ }^{1 *}$, H. L. Nedved ${ }^{1}$, N. V. Baliuk ${ }^{1}$, K. M. Herasimovich ${ }^{1}$, E. I. Rybinskaya ${ }^{1}$, I. A. Ovchinnikov ${ }^{1}$, N. A. Kopylova ${ }^{1}$, L. G. Yarullina ${ }^{2}$, N. A. Laman ${ }^{1}$

${ }^{1}$ V. F. Kuprevich Institute of Experimental Botany of the National Academy of Sciences of Belarus 17 Academicheskaya Street, 220072 Minsk, Republic of Belarus.

${ }^{2}$ Institute of Biochemistry and Genetics, Russian Academy of Sciences

71 Prospekt Oktyabrya, 450054 Ufa, Republic of Bashkortostan, Russia.

*Email: kalatskayaj@mail.ru

Treatment with Bacillus subtilis 47 mixtures with MeJ or with MeJ+SA of potato plants infected with the Y-virus and grown under water deficiency conditions, promotes active plant growth in comparison with infected plants and reduces the viral load by $16 \%$ and $12 \%$, respectively. At the same time, an increase in the proline content and the total peroxidase activity in the leaves of plants was revealed. The applied of $B$. subtilis alone or with SA did not cause a positive effect on reducing infection or preserving plant growth at water deficiency conditions.

Keywords: Solanum tuberosum L., Bacillus, subtilis 47, salicylic acid (SA), methyl jasmonate (MeJ), Y potato virus, proline, peroxidase 